\title{
An Encyclopedic Dictionary of MARXISM, SOCIALISM AND COMMUNISM
}

Economic, Philosophical, Political and Sociological Theories, Concepts, Institutions and Practices - Classical and Modern, East-West Relations Included

\section{J. Wilczynski Ph.D., D.Sc.}

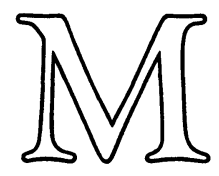


(C) J. Wilczynski, 1981

Softcover reprint of the hardcover 1st edition 1981 978-0-333-30689-5

All rights reserved. No part of this publication may be reproduced or transmitted, in any form or by any means, without permission.

First published 1981 by

THE MACMILLAN PRESS LTD

London and Basingstoke

Associated companies throughout the world

ISBN 978-1-349-05808-2

ISBN 978-1-349-05806-8 (eBook)

DOI 10.1007/978-1-349-05806-8

Filmset by Vantage Photosetting Co Ltd

Southampton and London

Reproduced from copy supplied 


\section{Preface}

Marxism was originally conceived in the early 1840 s and immediately became a controversial body of doctrine, destined to lead to far-reaching intellectual, social and political consequences. After Marx's publication of Capital vol. I in 1867 , virtually all thought on fundamental social issues has been either in support or in opposition to Marxist postulates and interpretations.

Precisely half a century later, the 'ten days that shook the world' resulted in the first Marxist government being successfully installed in power in Russia. By 1980 , the number of countries ruled by Marxist regimes had risen to $25-$ Afghanistan, Albania, Angola, Benin, Bulgaria, China (PR of), Congo, Cuba, Czechoslovakia, Ethiopia, the German DR, Guinea-Bissau, Hungary, Kampuchea (DPR of), Korea, Laos, Mongolia, Mozambique, Poland, Romania, the Somali DR, the USSR, Vietnam (PDR of), the Yemen and Yugoslavia. These countries now constitute more than one-third of the world. In addition, there are some 100 Communist parties in the capitalist world, not to mention an even larger number of socialist parties of one description or another.

The ideology ushered in by Marx and further developed by his followers has been eulogized by some as 'the greatest conception in the world. It links world wealth with world welfare' (G. Baker) and offers 'light in the darkness of a depressed world; hope and opportunity for all people; economic wisdom, political salvation, religious practice' (J. W. Bowen). But some others have denounced it as 'a fake, a comedy, a phantom and a blackmail' (B. Mussolini) and as 'the system which is workable only in heaven, where it is not needed, and in hell, where they have got it' (C. Palmer). Whether one agrees with Marxist ideas and Communist practices or not, one thing is certain - they are here to stay and they are commanding increasing interest not only from their supporters, but also from uncommitted observers as well as from enquiring critics.

This Dictionary provides a quick reference, explaining doctrines, terms and phrases for the student of the social sciences and the educated or curious public. The scope of the Dictionary is indicated by its sub-title. Non-Marxist theories are also considered, if Marxists have a definite view on them. Modern practices in the countries ruled by Marxist regimes are explained and all significant Communist and socialist parties in the world are described in detail appropriate to their importance. Included are also personalities of significant theoretical interest or major political consequence. 
The author's aim is to be as objective as is humanly possible, in what is after all the most controversial topic of our times. His task is to be informative and neither propagandist nor destructively critical. But he does not hesitate, still in the informative vein, to highlight the strengths and failings of Marxism, especially in comparison with capitalism.

This Dictionary is a product of several years' work carried out at different institutions. The author wishes in particular to thank the Central School of Planning and Statistics, Warsaw, the University of Pittsburgh and Carleton University, Ottawa, for financing or otherwise facilitating his research. He also wishes to acknowledge the untiring assistance given to him by the National Library of Australia and the Bridges Memorial Library of the Royal Military College of Australia. He further wishes to express his appreciation to Mr Alex Ikonnikov, of the Australian National University, for his valuable information and helpful advice.

University of New South Wales

JOZEF WILCZYNSKI

at Duntroon, Canberra 